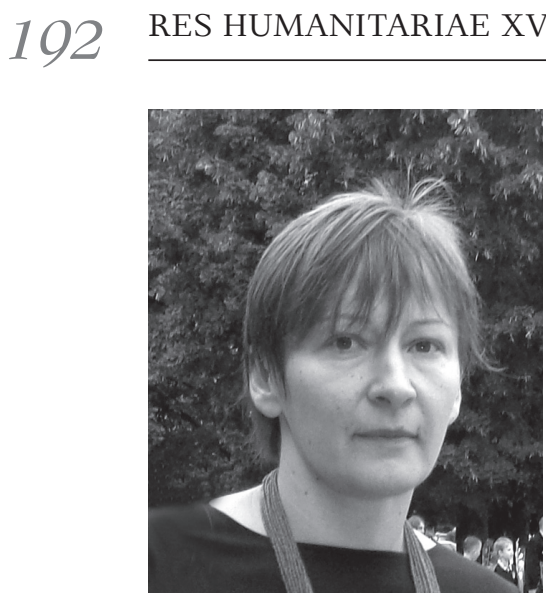

Silvija Papaurèlytė - Lietuvių kalbotyros ir komunikacijos katedros docentè, humanitarinių mokslų daktaré, Šiaulių universitetas.

Moksliniai interesai: kognityvinè lingvistika, lingvistinė kultūrologija, etnolingvistika.

Adresas: Povilo Višinskio g. 38, LT-76352 Šiauliai.

Tel. $8 \sim 69886003$.

El. paštas: silvijapapaurelyte@gmail.com.

Silvija Papaurèlytè: Ph. D. in Humanities, Assoc. prof. of the Department of Lithuanian Linguistics and Communication, Šiauliai University.

Research interests: cognitive linguistics, linguaculturology, ethno-linguistics.

Address: Povilo Višinskio str. 38, LT-76352 Šiauliai.

Phone: $8 \sim 69886003$

E-mail: silvijapapaurelyte@gmail.com.

\title{
Silvija Papaurèlytè
}

Šiauliu universitetas

\section{METAFORINIS KARO MODELIS LIETUVOS SVEIKATOS DISKURSE (1980-2001 M. $)^{1}$}

\section{Anotacija}

Straipsnyje pristatomas tyrimas skirtas sveikatos diskurso, kuris lietuvių kalbotyroje nėra aprašytas, specifikai aptarti: siekiama pagrịsti kalbamojo diskurso pavadinimą ir pateikti vieną iš galimų analizès būdų. Laikomasi kognityvinei lingvistikai artimo požiūrio ị kalbą, todèl sveikatos diskurso fragmentą siekiama aprašyti pasitelkus metaforinio modelio teoriją. Remiantis iš 1980-1989 m. dienraščio „Komjaunimo tiesa“ ir 1990-2001 m. dienraščio „Lietuvos rytas“ surinktais pavyzdžiais lyginama, kaip per daugiau nei 20 metų Lietuvos viešajame diskurse buvo realizuojamas metaforinis KARO modelis.

PAGRINDINIAI ŽODŽIAI: sveikatos diskursas, kalbos pasaulėvaizdis, metaforinis modelis.

\begin{abstract}
The research presented in this article discusses the specificity of health discourse, which has not been described yet in Lithuanian linguistics: it is strived to substantiate the title of the discourse under analysis and present one of the possible ways of analysis. The approach to language that is close to cognitive linguistics is taken into consideration, thus it is strived to describe the fragment of health discourse with reference to the theory of metaphorical model. On the basis of the examples drawn from daily newspaper "Komjaunimo tiesa" of
\end{abstract}

1 Straipsnis parengtas vykdant Lietuvos mokslo tarybos finansuojamą mokslo projektą Nr. VAT-12022 „Konceptualiosios metaforos viešajame diskurse“. 
1980-1989 years and daily newspaper "Lietuvos rytas" of 1990-2001 years it is compared how during more than 20 years, metaphorical WAR model has been realized in Lithuanian public discourse.

KEY WORDS: health discourse, language world view, metaphorical model.

DOI: http://dx.doi.org/10.15181/ rh.v0i16.1021

Diskursas - ne tik tekstas, bet ir socialinis kontekstas, kuris apibūdina komunikacijos proceso dalyvius, nuo foninių žinių priklausantị kalbos kūrimą ir suvokimą (Чудинов 2001, 104). Diskursas koreliuoja su kalbos pasaulèvaizdžiu, nes tekstuose fiksuojama konkrečiai kultūrai būdinga pasaulio samprata, todèl viešajame diskurse gali atsiskleisti esmingesni pasaulio suvokimo pokyčiai, kurie kasdienes aktualijas aprašančiuose tekstuose neišvengiami, o ì grožinę literatūrą ir liaudies žodinę kūrybą greičiausiai gali ateiti vėliau. Pabrèžiamas diskurso ideologinis aspektas (Vaskelienè 2007, 34), todèl tikètina, kad lyginant skirtingiems laikotarpiams priklausančius tekstus galima atskleisti kalbos priemonėmis koduojamus pasaulio suvokimo panašumus ir skirtumus, įvertinti pokyčius. Lietuvos viešuoju diskursu vadinami viešojoje erdveje funkcionuojantys ir visiems Lietuvos gyventojams prieinami tekstai, jų foną sudarantis socialinis kontekstas. Aprašius konkretų viešojo diskurso tipą galima apibūdinti kalbos pasaulèvaizdžio - konkrečioje kalboje užfiksuoto pasaulio vaizdo, kuris yra tikrovès interpretacija, o ne veidrodinis jos atspindys - fragmentą. Kalbos pasaulèvaizdis dažnai apibūdinamas kaip naivusis todèl, kad jis skiriasi nuo mokslinio pasaulèvaizdžio. „Mokslinis pasaulėvaizdis yra mokslinių žinių apie pasauli visuma, sukaupta tam tikrų mokslų tam tikru visuomenès raidos etapu“ (Корнилов 1999, 10), о kalbos pasaulèvaizdis apima tas žinias apie tikrovę, kurios apibendrinamos stebint tikrovę ir perimant paprasčiausią jutiminę ir kultūrinę patirtị. Lietuvių kalbotyroje viešojo diskurso tyrimai nėra gausūs. Daugiausia dėmesio sulaukia tekstai, kuriuose rašoma politikos ir ekonomikos klausimais (Arcimavičienė 2010a; Arcimavičienè 2010b; Arcimavičienė 2011, 95-100; Juzelènienè, Baranauskienė 2011, 101-105; Linkevičiūtė 2011; Rudaitienė 2011; Šeškauskienė, Urbonaitė 2007; Коницкая, Запольский 2011, 243-253; dar žr. Girčienė 2011, 2-9). Šios temos yra aktualios todèl, kad politikos ir ekonomikos srityse vyksta daug pokyčių, kurie daro įtaką kasdieniam kiekvieno žmogaus gyvenimui. Politiniame ir ekonominiame gyvenime daugiau ar mažiau gali dalyvauti visi pilnamečiai valstybès piliečiai: vyksta vietinès arba visos ša- 
lies valdžios rinkimai, kandidatai siekia rinkejjams suteikti kuo daugiau informacijos apie save, viešajame diskurse aptariami rezonansiniai politikos ir ekonomikos sričiu ịvykiai.

Šio straipsnio o b j e k t a s - iš Lietuvos viešuoju diskursu vadinamų tekstu išrinkti metaforinį KARO modelị realizuojantys pavyzdžiai. Pristatomo t y r i m o t i ks las - palyginti, kaip Lietuvos viešajame diskurse realizuojamas metaforinis KARO modelis. Darbo tikslui igyvendinti keliami šie u ž d a vi n i a i : nusakyti pagrindinius sveikatos diskurso požymius; iš 1980-1989 m. dienraščio „Komjaunimo tiesa“ ir 1990-2001 m. dienraščio „Lietuvos rytas“ numerių ${ }^{2}$ išrinkti metaforinio KARO modelio realizacijos pavyzdžius; atskleisti, kaip Lietuvos viešojo diskurso tekstuose detalizuojami tam tikri kalbamojo metaforinio modelio aspektai; apibūdinti dèl ekstralingvistinių veiksnių atsiradusius metaforinių modelių realizacijos skirtumus. Tyrimo išvados pagrịstos 217 pavyzdžių analize. Renkant pavyzdžius dèmesys buvo sutelktas tik ị straipsnius, kuriuose rašoma apie sveikatos išsaugojimą, ligas, gydymosi procesą, medicinos įstaigas, gydytojus, todèl galima teigti, kad šis tyrimas yra naujas ir aktualus, nes tokio pobūdžio diskursas lietuvių kalbotyroje apskritai netirtas: neapibrěžta šio diskurso tipo samprata, nenusakyta specifika. Tik iš dalies su sveikata ir medicina galima sieti tuos darbus, kuriuose sveikatos sritis pasirenkama kaip atskaitos taškas kitų sričių reiškiniams aprašyti (Šeškauskienė, Urbonaitè 2007, 68-73). Darbe taikyti konceptualiosios analizes, interpretacijos, aprašomasis ir skaičiavimo $\mathrm{m}$ e t o d a i .

Būtina pagrịsti kalbamojo diskurso tipo pavadinimą ir apibrèžti, kokio pobūdžio tekstai jam priskiriami. Gausiuose slavų kalbininkų darbuose nuosekliai vartojamas medicinos diskurso terminas (Голев, Шпильная 2012, 128-137; Зубкова 2005, 38-47, Зубкова 2007, 26-29; Жура 2008, 13-23; Мишланова 2002, 2009; Рудова 2008, 110-115; Соломенникова 2012, 27-32; Таценко, Москаленко, Переломова, Кондратюк 2012, 5-8). Minètuose straipsniuose rašoma ne tik apie ligų pobūdị, gydymą, bet ir apie gydytojo ir paciento bendravimą. Lietuviu kalbos žodyne medicina vadinamas ligu gydymo ir sueikatos saugojimo mokslas LKŽe. Kadangi sveikata (organizmo büklè, kai normaliai veikia visi organai; bendra organizmo būkle $L K Z ̌ e)$ yra natūrali būklè, kurią kartais gali tekti palaiky-

2 Straipsnio tekste laikotarpis iki $1990 \mathrm{~m}$. bus vadinamas pirmuoju, o nuo 1990 iki 2001 m. - antruoju. 
ti, o medicina - žmogaus protinès veiklos rezultatas, pagrịsta teigti, kad diskursas turètų būti vadinamas ne medicinos, bet sveikatos diskursu. Sveikatos diskursas turètu apimti ne tik tuos tekstus, kuriuose kalbama apie gydymą, gydytojų ir pacientų bendravimą (tai jau medicinos sritis), bet ir tuos, kuriuose pasakojama apie sveiką gyvenimo būdą, t. y. būklę be ligos, vadinasi, ir be medicinos. Visuose sveikatos diskurso tekstuose svarbiausia yra kalbėti apie žmogaus sveikatą: kaip ja reikia rūpintis ir kaip sveikata rūpinamasi, kokie pavojai tyko sveikatos ir kaip tų pavojų išvengti, ką reikia daryti, jei susergama, kaip iš tiesų elgiasi susirgę žmonès, ką jie išgyvena. Rašančiuosius apie sveikatą ir tikslinę tokių tekstų auditoriją sąlygiškai galima skirti i dvi grupes - specialistus ir nespecialistus. Žmonės, turintys medicinini išsilavinimą, gali kurti ir suprasti mokslinius tekstus, kuriuose gausu medicinos terminų, o patys tekstai orientuoti i išsilavinusị skaitytoją, kuris ieško tikslios informacijos. Ši sveikatos diskurso dalis realizuojama specializuotoje profesinėje literatūroje, todèl ir negalètų būti vadinama viešuoju diskursu. Nespecialistams skirtus tekstus galima vadinti mokslo populiarinimo tekstais. Tokiuose straipsniuose, knygose taip pat pateikiama informacija apie sveiką gyvenimo būdą, ligas, gydymą, tačiau ji yra supaprastinta, labiau siekiama paveikti skaitytojų protą ir emocijas. Apie sveikatą rašo didžiausi šalies dienraščiai, interneto svetainès (gausu ir vien tik sveikatos temoms skirtu interneto puslapiu), leidžiama šviečiamojo pobūdžio literatūra ${ }^{3}$. Sveikatos diskurso tekstuose galima įžvelgti du svarbiausius tikslus: informuoti ir ittikinti. Pateikiama informacija apie sveiką gyvenimo būdą, ligas, gydymo procesą, gydytojų darbą, siekiama paskatinti skaitytojus atitinkamai elgtis arba nesielgti, apibūdinamos galimos elgesio pasekmès. Teksto autorius nėra tiesiogiai suinteresuotas, ar jam pavyko įtikinti skaitytojus elgtis būtent taip, kaip jis pataré, o ne kitaip, nes jo paties gyvenimui potencialių skaitytoju gyvenimo būdas įtakos neturi (plg. rinkimų agitacijos tekstus, kuriuos rašiusiam žmogui svarbu, kad pavyktų skaitytojų nuostatas paveikti taip, kaip naudinga jam). Viešojo diskurso tekstuose aprašoma ta pati tikrovè, tačiau tekstuose atskleidžiamas pasaulio vaizdas yra nulemtas konkretaus diskurso pobūdžio: temos, i kurias sutelkiamas dèmesys, iš dalies lemia tai, kokie raiškos būdai bus pa-

3 Toks skirstymas koreliuoja su santykiu tarp naiviojo ir mokslinio kalbos pasaulèvaizdžių, nors negalima teigti, kad nespecialistams skirtuose tekstuose pateikiama visiškai primityvi ir tikrovès neatitinkanti informacija. 
sirinkti. Rašant apie sveikatą nebus išsiversta be medicininio išsilavinimo neturinčiam kalbos vartotojui suprantamų terminų, be to, atitinkamomis kalbinėmis priemonėmis reikia išreikšti daugiausia šio viešojo diskurso tipo dèmesio sulaukiantị skirtumą tarp sveikos ir nesveikos organizmo būklès.

Straipsnyje remiamasi kognityviniu požiūriu į kalbą. Tikètina, kad diskurso tipai gali būti siejami su atitinkamais metaforiniais modeliais. Sveikatos diskurso specifiką siekiama aprašyti pasitelkiant metaforinio KARO modelio analizę. Metaforinis modelis - kalbos vartotojų sąmonėje egzistuojanti ir / arba susidaranti ryšio tarp konkrečiu ir abstrakčių konceptų sferų schema, kurią parodo formule X yra Y, pavyzdžiui: GYDYMO PROCESAS yra KARAS. GYDYMO PROCESAS šiuo atveju yra tikslo sfera, nes apie ją kalbama, o KARAS yra ištakų sfera. Santykis tarp formulès komponentų suprantamas ne kaip sutapatinimas, bet kaip panašumas ${ }^{4}$. Ištakų sfera yra tikslo sferos modeliavimo pag rindas. Taip modeliuojant tikslo sferos struktūra išsaugo ne tik ištakų sferos struktūrą, bet ir jos emocinị potencialą (Чудинов 2003). Žmonès tikslo sferą ne tik suvokia kaip ištakų sferą, priskiria jai tokias pačias charakteristikas, bet ir vertindami tikslo sferą linkę elgtis taip, lyg vertintų ištakų sferą. Jeigu apie gydymą kalbama kaip apie karą, vadinasi, vartojami tie patys žodžiai, kurių reikètų norint apibūdinti karo priežastis, kovos eigą ir baigtị. Kadangi karas visada yra vertinamas neigiamai, gydymą kaip karą suvokiantis žmogus ligą taip pat vertins neigiamai. Jeigu kitas abstraktus fenomenas, pavyzdžiui, politika, suvokiamas kaip mechanizmas (tai iliustruoja teiginiai pakeitè šalies kursa, ivykiu grandine, reforma nustojo buksuoti), skirsis ir vertinimo kryptys. Mechanizmai yra tam tikros garantijos, stabilumo ženklai, jie vertinami teigiamai, vadinasi, taip suvokiantis politinę veiklą žmogus ją taip pat vertina teigiamai. Kuo didesniu pavyzdžių skaičiumi remiamasi, tau daugiau galimybių išsamiau atskleisti tas ištakų sferos koncepto detales, kurios perkeliamos ị tikslo sferą.

Su metaforiniu modeliu siejami tipiški scenarijai, apimantys ištakų sferai būdingas situacijas. Situacijas Anatolijus Čiudinovas vadina freimais. Freimai yra atskiri kalbos pasaulèvaizdžio fragmentai, apimantys tas žinias, kurios stereotipiškai (paprastai) siejamos su metaforiniame modelyje api-

4 Metaforinio modelio samprata koreliuoja su konceptualiosios metaforos apibrèžimu (plg. Lakoff, Johnson 1998; KCKT 1996, 55). 
būdinama situacija. Freimų visuma (būdingiausios situacijos, išdèstytos joms ịprasta seka) sudaro vienam metaforiniam modeliui būdingą tipini scenarijų. Straipsnio autore siūlo terminą freimas keisti anksčiau ị lietuviu kalbą atejjusiu žodžiu tema. Daugiau informacijos suteikia konkrečių freimo, t. y. temos, aspektų - slotu aprašymas. Pagal analogiją su žodžiu tema slotus būtų galima vadinti potemèmis. Kaip pavyzdį A. Čiudinovas pateikia metaforinị KARO modelį. Be kitų, ì KARO modeliui būdingą scenariju įeina tema Ginklai. Jeigu tik yra įvairių metaforinio modelio realizacijos pavyzdžių, galima kalbèti apie potemes, nes ginklai gali būti šaltieji, šaunamieji. Charakterizuojant potemę vartojamas koncepto terminas, o konceptai pavadinami kasdienès kalbos žodžiais (Чудинов 2001, 21). Metaforiniai modeliai pirmiausia yra paremti jutimine žmoniu patirtimi, siejami su paprasčiausiomis žmogaus kūno ypatybėmis, judesiais, kurie kalbėtojui yra tokie aiškūs ir suprantami, kad egzistuojančius dèsningumus įmanoma perkelti ir į kitas sritis, kurios yra abstrakčios ir sunkiau apibūdinamos. Be to, egzistuoja nacionalinè mąstymo specifika, vadinasi, gali būti ir nuo kultūrinès patirties priklausančių konkrečiai tautai būdingų metaforinių modelių skirtumų. Kalba semantineje sistemoje tik atskleidžia tuos skirtumus, kurie komunikaciniu atžvilgiu tautai yra relevantiški (Стернин 1998, 30). Aprašius konkrečiai kalbai ir kultūrai būdingų metaforinių modelių įvairovę būtų įmanoma iš dalies aprašyti ir ta kalba kalbančiu žmonių mentalitetą. Tai, kurie metaforiniai modeliai yra produktyvesni vienu ar kitu laikotarpiu, turètu priklausyti nuo ekstralingvistinių aplinkybių: tą, kas žmonėms yra aktualu, apie ką daug kalbama, linkstama pasitelkti modeliuojant tikrovę. Be to, subordinaciniai ryšiai tarp tipinio scenarijaus, temų ir potemių gali būti pasitelkiami kaip tertium comparationis siekiant iqvertinti skirtingoms kalboms arba skirtingiems laikotarpiams būdingo pasaulio suvokimo panašumus ir skirtumus.

Metaforinis modelis tekste pasitelkiamas ne tik todèl, kad jis yra būdas informacijai apie pojūčiais nesuvokiamus abstrakčius fenomenus perteikti, bet ir siekiant konkretaus diskurso tekstams būdingų tikslu - informuoti, ittikinti etc. Atitinkami metaforiniai modeliai siejami su konkrečių idèjų raiška. Pavyzdžiui, racionalumo idejją iškeliantys metaforiniai modeliai (STATINIO, MECHANIZMO, TRANSPORTO, OBJEKTO) dèmesį sutelkia į tai, kas yra tvarkinga ir prognozuojama. İ konfliktiškumo, priešpriešos raišką orientuoti KARO, ŽAIDIMO, SPORTO metaforiniai modeliai. 
Abstrakčiu fenomenų natūralumą, organiškumą atskleidžia ORGANIZMO, AUGALO, SVEIKATOS metaforos, o su tuo, kas yra ịsivaizduojama, netikra, siejami RELIGIJOS, MITOLOGIJOS, TEATRO, ANTGAMTINIŲ BŪTYBIŲ metaforiniai modeliai (Баранов, Михайлова, Шипова 2006, 63). Tikètina, kad apibrèžtas metaforinių modeliu inventorius gali dominuoti vienuose ar kituose tekstuose.

Karas žodyne apibūdinamas kaip ginkluotas susidūrimas tarp valstybiu ar dideliu visuomenés grupiu LKŽe. Istorikas Darius Baronas rašo, kad karas yra „organizuota veikla, kuria tam tikrais veiksmais siekiama atimti kitam žmogui tai, kas jam brangiausia - gyvybę““ (Baronas 2000, 4).

Metaforini KARO modeli vieni kalbininkai apibūdina kaip reikšmingą visais laikotarpiais (Чудинов 2001, 53), kiti teigia, kad toks suvokimo būdas unikalus, būdingas nedaugeliui kalbų (Marcinkevičienė 1995, 121). Aišku, kad dažniau šis modelis tikrovei suvokti turètų būti taikomas tada, kai šalyje kyla neramumai, vyksta kova su vidaus ir išorès priešais. Kai kurios visuomenès karo nèra išgyvenusios (Baronas 2000, 4), todèl tikètina, kad metaforini KARO modeli joms priklausantys žmonès pasauliui suvokti taikys rečiau (su tokiu pasaulio suvokimo būdu galima susipažinti, pavyzdžiui, skaitant mokslinę literatūrą) arba visai netaikys. Pasak Rūtos Marcinkevičienės, „lietuviu kalbos karo metafora yra dvejopa: senoji tradicinè, apimanti žmonių tarpusavio santykius, akademini gyvenimą, sportą, teismus ir kai kurias kitas gyvenimo sritis, pvz.: ginti disertaciją, teisiamąij; laimèti varžybas $\langle\ldots\rangle$, ir naujoji sovietinè, atėjusi per politinius ir ideologinius tekstus, o iš ju pasklidusi publicistikoje ir kasdienejje šnekamojoje kalboje: liaudies, klasinis, marksizmo priešas; darbininkų ir valstiečių kovos už taiką avangardas $\langle\ldots\rangle$. Ši metafora $\langle\ldots\rangle$ atspindèjo vieną esmingiausių totalitarizmo idèjų, kad pasaulis yra radikaliai pasidalijęs ị dvi priešiškas ir nesutaikomas stovyklas“ (Marcinkevičienè 1995, 121). KARO modelis ir toliau taikomas kalbant apie politines realijas, nors vyraujanti ideologija ir pačios politinès realijos keičiasi (Чудинов 2001, 53-54). Каras pirmiausia yra konfliktas (Baronas 2000, 4). Vadinasi, jeigu suvokiant abstraktų fenomeną taikomas metaforinis KARO modelis, to abstraktaus fenomeno esmę sudaro dviejų ar daugiau subjektų susidūrimas, po kurio paprastai lieka vienas laimètojas. Kita konflikto šalis arba žūsta, arba labai nukenčia. Karas yra žmonių bendravimo forma, sukelianti jiems fizini ir / ar dvasini skausmą. Nemalonus ne tik pats karo rezultatas, bet ir jo 
eiga. Taip suvokiamas abstraktus fenomenas sukelia nemalonius išgyvenimus dar jo esmès nepatyrusiam žmogui, kuris iš savo kultūrinès patirties, išsilavinimo žino, kas yra karas, kaip karo metu elgiamasi ir kokie gali būti kariaujančių šalių tikslai.

Renkant sveikatos diskurso pavyzdžius iš 1980-1989 m. dienraščio „Komjaunimo tiesa“ ir 1990-2001 m. dienraščio „Lietuvos rytas“ numeriu pastebėta, kad dažnai pasitelkti metaforinị KARO modelį linkstama ir kalbant apie žmogaus sveikatos būklę. Tokio dèsningumo priežastys įvairios. 1980-1989 m. viešojo diskurso tekstai turèjo paklusti totalitarizmo idejjoms ir atskleisti bendrąią kovos atmosferą. Antrasis laikotarpis, t. y. paskutinysis XX a. dešimtmetis, išsiskiria kaip esminių pokyčiu laikas: 1990 m. Lietuva paskelbia atkurianti nepriklausomą valstybę, šalyje pradeda rastis politinès partijos, todèl kovos ideja ir toliau išlieka svarbi. Analizuoti pasirinkti vienodos trukmès - 10 metų - laikotarpiai. Sveikatos temoms viešajame diskurse ne visada skirta vienodai dèmesio. Devintojo dešimtmečio pradžioje publikuotas vos vienas kitas straipsnis, kurị galima laikyti sveikatos diskurso dalimi: rašyta apie gydytojų darbą (L. Dolgoborodova „Greitosios šiokiadieniai“ KT 1980-01-09, T. Tubinienè „Žmogus, kurio visi laukia“ KT 1984-11-27, D. Martišiūtè „Žmogaus gerumo vèliava“ KT 1981-03-27), skirta dèmesio ligų prevencijai ir siekta propaguoti sveiką gyvenimo būdą („Už sveiką žmogų“ KT 1981-02-04, G. Petkūnienė „Trumparegysté“ KT 1982-04-10, St. Jurgutis „Pagalba blaivybei“ KT 1980-09-25, P. Čygaitė „Tegu liga aplenkia namus“ KT 1984-09-22, A. Smailys „Tiesiog proporcingai surūkytų cigarečių kiekiui“ KT 198109-10). Laikotarpio viduryje pagausėja straipsnių, kuriuose rašoma apie alkoholizmą ir narkomaniją (A. Vingras „Priešas Nr. 1“ KT 1986-12-31, J. Loiba „Diagnozè - narkomanija“ KT 1986-07-09, „Pražūtingas apsvaigimas“ KT 1989-01-17, J. Pekarskis „Vaikščiojimas pakeltais tiltais“ KT 1987-06-26). Taip buvo reaguojama ị visoje buvusioje TSRS paskelbtą kovą su girtavimu. Baigiantis XX a. devintajam dešimtmečiui viešajame diskurse ėmé rastis naujų temų, kurios dešimtajame dešimtmetyje buvo intensyviai plètojamos: daug rašoma apie AIDS (J. Čekatauskaitė „Pasaulis vienijasi prieš AIDS“ LR 1992-08-08, J. Laužikaitè „AIDS - socialinis testas visuomenei: elgesys su infekcijos nešiotojais parodo tikrąią jos vertę“ LR 1994-11-30), pasakojama, ką išgyvena vèžiu sergantys žmonès (R. Aleknienè „Mano gyvenimo metai: nusprendžiau nebijoti vėžio ir mir- 
ti stovėdama“ LR 1997-12-27, J. Kurtinaitis „Vèžio diagnozavimą lemia medikų ir ligonių pastangos“ LR 1998-10-10), imama rašyti apie labai sunkiomis ligomis sergančius vaikus (A. Treščina „Liga, dèl kurios vaikai gali nesulaukti pilnametystès“ LR 1995-06-06). Pirmajam laikotarpiui priklausančiuose tekstuose ši tema buvo apskritai nutylima. Antrasis laikotarpis dar išsiskiria ir tuo, kad viešajame sveikatos diskurse buvo reaguojama ị rezonansinius i̇vykius (M. Deksnys, D. Jonušienè, L. Valonyte „Statomos užkardos kempinligei“ LR 2001-02-09).

Nors lyginami laikotarpiai ir skiriasi straipsnių apie sveikatą ir ligas skaičiumi (nuo $1991 \mathrm{~m}$. tokių tekstų ima daugèti), metaforinio KARO modelio produktyvumas panašus: iš pirmojo laikotarpio tekstu išrinkti 99 modelio realizavimo pavyzdžiai, iš antrojo -118 .

Aprašant metaforinio KARO modelio realizaciją viešajame sveikatos diskurse tik iš dalies remiamasi A. Čiudinovo pateiktu aprašymu, kuriame atskleidžiama, kaip kalbamasis modelis gali būti detalizuotas politikos diskurse (Чудинов 2001, 53-58). Išanalizavęs iš Rusijos politini gyvenimą aprašančiu tekstu surinktus pavyzdžius, mokslininkas padare išvadą, kad žmonių sąmonè vis dar tebėra militarizuota: nors tikrų karo veiksmų tuo metu šalyje nèra, kalbama apie vykstančius įvairaus pobūdžio karus (pavyzdžiui, propagandinį), egzistuoja kovotoju armijos, kuriose esama ir eilinių, ir generolų. Kariai turi ginklų, jie puola, kovoja, yra sužeidžiami, miršta arba pasveiksta. Taip sukuriama visu karo su visais atmosfera, kuri atitinkamai veikia žmoniu pasąmonę. Politikos diskursas turi atskleisti šiai visuomeninio gyvenimo sferai būdingą įtampą, kai nuo žodžių karo gali būti pereita prie tikrų karinių veiksmų. Sveikatos diskurso temos yra nevienodos. Kai kalbama apie sunkias ligas, kurios gali baigtis žmogaus mirtimi, taip svarbu išreikšti konflikto tarp ligos ir žmogaus, gydymo proceso keliamą įtampą. Lengvesnès ligos, sveiko gyvenimo būdo tema su konfliktiškumu susijusios mažiau - svarbiau yra informuoti skaitytoją apie pasirinkimo galimybes ir netiesiogiai nurodyti, kas jo laukia, jeigu rekomendaciju nebus laikomasi.

Abiem lyginamiems laikotarpiams priklausančiuose tekstuose išsamiausiai atskleidžiamos Karo veiksmų ir ginklų ir Karo pradžios ir jo rezultatų temos. Vadinasi, šiame lygmenyje fiksuojama analogija tarp abiejų laikotarpių. Skirtumų esama atskleidžiant atskiras potemes. Tik 1980-1989 m. laikotarpiui priklausančiuose pavyzdžiuose pateikta užuo- 
minų ị karinių pajègų struktūrą, pvz.: Interferonas tarsi pasienio užkardos būrys pirmasis priima priešininko smūgi R. Belovas „Kuo gydysimès rytoj“ KT 1986-02-11; Tarp nuteistuju yra medicinos darbuotoju, nors, atrodytu, būtent jie turètų būti pirmosiose kovotoju su narkomanija gretose „Pražūtingas apsvaigimas“ KT 1987-01-17. Galima daryti prielaidą, kad su liga kovoja didelis ir tvarkingai išrikiuotas būrys, o grupe karių yra sutelkta pasienio užkardoje. Vis dèlto apskritai ši tema lyginamų laikotarpių tekstuose nedetalizuojama.

1. Karoveiksmai ir ginklai

\subsection{Karo veiksmai}

Šią potemę lyginamų laikotarpių tekstuose atskleidžia ne tie patys konceptai. Bendra yra tai, kad daugiausia pavyzdžiu, kuriuose karo veiksmai apibūdinami bendriausios reikšmès žodžiu kovoti. Šis veiksmažodis gali būti vartojamas su keliais prielinksniais, taip atskleidžiamas kovos pobūdis. Jeigu šalia veiksmažodžio prielinksnis su, vadinasi, apibūdinama situacija, kai kariaujama su priešininku, kuris nesantaiką pradejjo pirmasis, be to, taip norima pabrèžti, į ką nukreiptas pats veiksmas (Šukys 1978, 99). Remiantis kalbininkų rekomendacijomis, prielinksnio prieš su veiksmažodžiu kovoti geriau nevartoti (Šukys 1978, 91).

Nagrinėjamų laikotarpių tekstuose dominuoja veiksmažodžio kovoti ir prielinksnio su junginiai. Vadinasi, realizuojant metaforinį KARO modeli svarbiausia atskleisti konfrontacijos tarp žmogaus (žmonių grupės) ir ligos, negalavimo motyvą. Veiksmo objektai 1980-1989 ir 1990-2001 m. straipsniuose sutampa tik iš dalies. Abiejų laikotarpių tekstuose ne vienas pavyzdys, kuriame nurodyta, kad kovojama apskritai su liga, plg.: Bet virpančiomis rankomis nepakovosi su liga, mirtimi... I. Žiemyte „,... Ir gerąią savo gydytojąa KT 1982-06-19; Po gripo ilgam sumažéja organizmo atsparumas: jis nepajegia kovoti su jokiomis ligomis V. Kramarauskienè „Saugokimès peršalimo ligu““ KT 1983-01-06 ir Jauni žmonés, likimo pasmerkti kovoti su liga $<\ldots>$ N. Augustinienè „Ar Lietuva laikosi diabetikus ginančios Sent Vinsento deklaracijos?" LR 1995-02-28; Tačiau Vakaruose jau žinoma, kad organizmui reikèty leisti pačiam kovoti su liga L. Lileikienė „Po pirmụjų peršalimo požymių nebūtina iškart griebtis antibiotikų“ LR 
1996-10-05. Nesutampa kaip kovos objektai aprašomos konkrečios ligos. 1980-1989 m. „Komjaunimo tiesos“ tekstuose minima, kad kovojama su tuberkulioze, „mokykline“ trumparegyste, alkoholizmu, reumatu, smegenu pabrinkimu ir suspaudimu, narkomanija, toksikomanija, AIDS, alergija, psichine liga. 1991-2001 m. buvo svarbu rašyti, kad kovojama su alkoholizmu, infekcija, širdies ir kraujagyslių ligomis, AIDS, sifiliu, stresu, narkomanija, mūsų amžiaus ligomis ${ }^{5}$, minimas karas su vèžiu. Tarp tų ligų, kurių nebuvo svarbu aprašyti pirmojo laikotarpio tekstuose, beveik nèra tokių, kuriomis žmonès pradejjo sirgti būtent tik XX a. pabaigoje. Dalis temų 1980-1989 m. periodikoje, matyt, paprasčiausiai buvo nutylimos. Minètina, kad šio laikotarpio tekstų autoriai rašo, jog turètų būti kovojama ne tik su ligomis, bet ir su ligas galinčiu paskatinti blogu žmogaus elgesiu, pvz.: Iš to aišku, kaip svarbu kovoti su pradedančiu paaugliu, ypač mergaičiu, blogais ịpročiais A. Smailys „Tiesiog proporcingai surūkytų cigarečių kiekiui“ KT 1981-09-15; Todèl visų mūsu pareiga visomis išgalemis kovoti su girtuokliavimo papročiais A. Vingras „Priešas Nr. 1“ KT 1986-12-31. Aprašomos problemos (rūkymas, girtavimas) neišnyko ir vèliau, tekstuose kovos su jomis galimybè neminima. Išskirtinis pirmojo laikotarpio požymis - tie kovos objektai, kurie ne tokie konkretūs, labiau susiję su sveiku gyvenimo būdu. Buvo numatoma galimybẻ kovoti už sveiką aplinką, sveiką gyvenimo būdą, sveiką žmogų, sveiką Lietuvos pilietį, sveiką, dorą jaunuoli, plg.: Ir už sveika, dora jaunuolị turi kovoti ne tik medikai „Už sveiką žmogu““ KT 1981-02-04; Manau, svarbiq reikšmę kovojant už būsimuju karty sveikatingumq turi genetikos kabinetas A. Urbelionis „Kad neišsektų sveikatos šaltiniai“ KT 1986-03-11; <..> ragindami isitraukti j aktyviq kovq už sveikq gyvenimo būdq „Iš jaunumès gyvenkime sveikai“ KT 1987-12-24. Po 1990 m. šiam klausimui dèmesio nebeskiriama.

Jonas Šukys yra nurodęs, kad „daiktavardis kova, lygiai kaip veiksmažodis kovoti, gali būti vartojami pasirinktinai su prielinksnių dèl arba $u z ̌$ konstrukcijomis, nors esama šiokio tokio skirtumo. <...> Prielinksnis del turètų būti pasirenkamas, kai objektas, dèl kurio kovojama, yra prarastas, reikia ji atgauti. Prielinksnis $u z ̌$ tinka, kai kalbama apie objektą, kurị reikia apginti ir išsaugoti. Jei sakoma Kova dèl taikos, pabrěžiama priežastis, o sakant Kova už taikq - nuolatinis objektas“ (Šukys 1978, 34). Tekstuose

5 Orientuojamasi ị išsilavinusị skaitytoją. 
tokio santykio kartais nesilaikoma. Pavyzdžiui, 1980-1989 m. „Komjaunimo tiesos“" straipsniuose rasta pavyzdžių, kuriuose minima, kad kovojama dèl sveikatos ir dèl gyvybès. Vadinasi, šios dvi vertybès suvokiamos kaip tokios, kurias reikia atgauti. Susigrąžinti sveikatą bent jau teoriškai įmanoma, tačiau gyvybès praradimas yra baigtinis veiksmas, susigrąžinti jos nebeįmanoma, todèl prielinksnio dèl pasirinkimas gali būti suvokiamas kaip siekis dramatizuoti situaciją, pvz.: Gydytojai ilgai ir pasiaukojančiai kovojo dèl šios dvidešimt dvejų metu moters gyvybès, atsidūrusios pavojuje J. Loiba „Diagnozé - narkomanija“ KT 1986-07-09. Daugiau yra objektų, kurie, remiantis prielinksnio $u z ̌$ pasirinkimu, suvokiami kaip tebeesantys aprašomoje tikroveje, bet reikalaujantys rūpinimosi. Tokia yra gyvybė: $P u-$ santros valandos kovojama už ligonio gyvybę L. Dolgoborodova „Greitosios šiokiadieniai“ KT 1980-01-25; Bet procentai tik popieriams, o čia dirbantiems - nuolatiné kova už žmogaus gyvybe I. Šalkauskienė „Atmintis“ KT 1981-04-22. Būtinybẻ kovoti už gyvybę atskleidžiama ir 1990-2001 m. „Lietuvos ryto“ tekstuose, plg.: A. Treščina „Dèl neišnešiotų kūdikių gyvybès medikai kovoja tik pasitarę su tèvais“ LR 1996-03-11; Už mažeikiškiu pražiūrèto R. Valatkos gyvybę kovojo Šiauliu, Vilniaus ir Kauno medikai L. Lileikienè „Kūdikio negalavimų medikai nepastebėjo 18 valandų“ LR 1996-08-06.

Galima teigti, kad ìvairiau, vadinasi, ir detaliau potemès turinys atskleidžiamas antrojo laikotarpio straipsniuose. Iš 1980-1989 m. tekstų išrinktuose pavyzdžiuose minimi atskiri veiksmai, galintys nulemti karinio konflikto eigą. Liga apibūdinama kaip stiprus priešininkas, kontaktas su ja gali būti lemtingas: Tai buvo pirmasis susidūrimas su liga, kai mano rankose atsidūré brangiausio, artimiausio žmogaus gyvybẻ V. Lukšytė „Dovanojanti viltị“ KT 1984-06-02. Liga pirmoji imasi aktyvių veiksmų, nulemiančių aiškią kovos strategiją: Po pirmosios reumato atakos 10-15 proc. žmoniu išsivysto širdies ydos P. Čygaitė „Tegu liga aplenkia namus“ KT 1984-09-22; Čia virusas greit „,persitvarko“: savo baltymus priderina prie ląsteles apvalkalų baltymu, užsimaskuoja J. Lelys „Būti ar nebūti“ KT 1989-02-18. Žmogus nèra bejejgis, gali imtis atsakomųų veiksmų, nors ne visada tai suspejja padaryti: O už lovos galo jau brazda mirtis. Ir gyvybès skydo neberra „Vienetas už gydymą“" KT 1986-04-26.

1990-2001 m. laikotarpio tekstuose atskleidžiant metaforinio KARO modelio potemę Karo veiksmai apibūdinamos situacijos iki žmogaus kon- 
takto su liga. İtampą turètų skatinti kuriami vaizdai, kad sveikatos bėdos žmogaus laukia visur, net ir ten, kur nesitikima, pvz.: A. Treščina „Medikai nutyli tiesą apie ligoninèse tykančias infekcijas“ LR 2000-06-10; D. Jonušienė „Kojų ligos mikrobai tyko ir baseinuose, ir svetimose šlepetėse“ LR 2001-05-12. Žinant apie būsimą ligos grèsmę įmanoma daryti tai, kas galimą pavojų sumažintų. Veiksmai gali būti ir vienkartinė akcija, ir nuolatinis darbas, plg.: M. Deksnys, D. Jonušienè, L. Valonytė „Statomos užkardos kempinligei“ LR 2001-02-09; Skiepai-inaktyvuotas ligos sukèlëjas, negalintis sukelti ligos, bet sugebantis mobilizuoti žmogaus imuninę sistema ilgam pagaminti daug specifiniu antikūnu A. Treščina „Erkių perduodamų infekcinių ligų išsigando ir Vyriausybès nariai“ LR 1998-07-25. Taip veikdamas žmogus rengiasi karui, bet su pačia liga dar nèra susidūręs. Tekstuose numatoma tokia galimybe, kai subjektas, siekdamas potencialu priešininką susilpninti, pirmasis puola: Šiai ligai reikia suduoti išankstinị smūgi J. Čekatauskaitè „Pasaulis vienijasi kovai prieš AIDS“ LR 1992-08-08.

Daug dažniau aktyvesné yra liga: ji pirmoji pradeda konfrontaciją su subjektu ir taip paskatina intensyvius karo veiksmus. Puolimas gali būti dvejopas: arba iškart ir staiga, arba sudarius iliuziją, kad jokių pavojų nėra, plg.: Hepatito $C$ virusas yra klastingas-iš pradžiu jis sugyvena su organizmo imunine sistema, ji nelabai puola virusą, o šis nelabai kenkia A. Treščina „Hepatitu C galima užsikrèsti net ir valantis dantis“ LR 1998-10-28; Krūties véžys mane užpuolè staiga R. Aleknienè „Mano gyvenimo metai: nusprendžiau nebijoti vėžio ir mirti stovèdama“ LR 1997-12-27.

Antrojo laikotarpio tekstuose demesio skiriama ir karo dalyvių skaičiui apibūdinti. Žmogaus santykis su liga gali būti nusakomas kaip dviejų priešininkų susitikimas, kuriame daugiau niekas nedalyvauja, plg.: Ir vèl teko vienai stoti kaktomušon su liga L. Lileikienè „Žvilgsnis ị Prezidento aki suvirpino gydytojos širdį“ LR 2001-06-16. A. Bailey „Vašingtone tęsiasi lietuvès dvikova su baisiąja liga“ LR 1993-09-28. Toks susidūrimas gali būti suvokiamas ir kaip beginklių, ir kaip turinčiu ginklų žmonių konfrontacija. Kai ligos procesas apibūdinamas kaip grumtynès, ginklų tema išvis neaktualizuojama: Ypač sunku grumtis su liga tapo nepagydomomis ligomis sergantiems žmonėms A. Treščina „Lengvatinių vaistų sąmokslas: kas ir ką tausoja?" LR 1995-07-04.

Dar vienas veiksmas - gynyba - priskiriamas ne pačiam žmogui, o jo imuninei sistemai, suvokiamas kaip išmokstamas: Imunitetas, ginantis or- 
ganizma nuo išorinio poveikio <...> P. Breivis, D. Adomaitienė „Mikroelementu stoka silpnina imunitetą" LR 1998-12-19; <..> dar nesusiformavusi ju imuniné sistema nemoka apsiginti nuo meningokoko paviršiuje esančiu medžiagu L. Lileikienè „Mirtinai pavojingą infekciją išduoda raudonos dèmelès“ LR 2000-02-24. Žmogaus imuninè sistema atskiriama nuo jo paties, nes ji gali padèti išvengti ligų. Kai subjektas sẻkmingai priešinasi, ligai nebelieka vietos: Plaučì vėžys atsitraukia J. Kurtinaitis „Vèžio diagnozavimą lemia medikų ir ligonių pastangos“ LR 1998-10-16.

\subsection{Ginklai}

Ši potemè taip pat išsamiau atkleista antrojo laikotarpio tekstuose. 1980-1989 m. „Komjaunimo tiesos“ numeriuose rastas vienas pavyzdys, aktualizuojantis ginklu temą: Pats svarbiausias bet kurio gydytojo ginklas žodis E. Laurinaitis „Žodis - pagrindinis vaistas“ KT 1985-12-13. 19902001 m. „Lietuvos ryto“ tekstuose tokių pavyzdžių daugiau. Minima ginklų visuma: $<\ldots>$ gydymas senovés rytiečių metodu daugeliu atveju pasiteisino ir praturtino mūsu laiku medicinos arsenala J. Valiukẻnas „Atskleidžiamos rytų medicinos paslaptys" LR 1994-04-13. Tekstuose minimi konkretūs ginklai - arba itin galingi sprogstamieji, arba tokie, kuriuos pagal pateiktus požymius galima priskirti ir prie šaunamųjų, ir prie šaltųjų, plg. Virusa ypač dažnai perduoda motinos naujagimiams. Tokia jau vaikystëje padèta „,bomba“ skaudžiai atsiliepia vèliau R. Lileikienè „Manikiūro procesas gali baigtis B hepatitu“ LR 1998-01-13; A. Treščina „Krūties vėžio taikinys keturiasdešimtmetès moterys“ LR 1995-11-21. Atkreiptinas dèmesys, kad taikant metaforinį KARO modelị tarp negausių bandymų pasitelkti analogijas su ginklais nėra tokių pavyzdžių, kuriuose būtų minimi patys naujausi ir šiuolaikiškiausi (atominès galvutės ir kiti masinio naikinimo ginklai) arba iki parako atradimo vartoti ginklai (kardai, kalavijai, ietys).

\section{Karo pradžia ir jo rezultatai}

Tema Karo pradžia ir jo rezultatai nagrinejjamų laikotarpių tekstuose atskleidžiama skirtingai. Kadangi kalbant apie kovą su ligomis karo pradžia, t. y. jo priežastys ir sukẻlejai, yra ir taip aiškūs, šiam etapui skiriama mažiau dėmesio, viskas sutelkiama ị veiksmų pabaigą. KARO modelis numato dvejopą baigtị: karą laimi arba liga, arba žmogus. Iš kal- 
bos priemonių, skirtu žmogaus pergalei aprašyti, įvairovès galima spręsti, kad labiau orientuojamasi i tą situaciją, kurioje stipresnis lieka žmogus. Lyginamų laikotarpių tekstuose daugiau tokių pavyzdžių, kuriuose karo pabaigą apibūdina veiksmažodis įveikti. Tekstuose sutampa dalis objektų, kuriuos, remiantis lietuvių kalbos pasaulèvaizdžio logika, žmogus pajėgus ìveikti. Tai liga, negalia, pvz.: Galvoja, jog patys pajegs ịveikti liga „Ilgas grįžimas į save“ KT 1984-04-25; Pats ịveikiau savo negaliq ir panorau padèti kitiems V. Jakimavičienè „Mokykimès būti sveiki“ KT 1983-04-07; $<\ldots>$ reikia ir savo valios negalavimams jiveikti J. Žilinskas „Reabilitacija“ KT 1981-08-08; < ...> lieka liga - baisus monstras, kurį reikia ịveikti I. Liutkevičienè „Ligoninès vaikai: motinų viltis miršta paskutinë“ LR 1993-0913; I mokykla < ...> atvyksta vyrai, kenčiantys nuo impotencijos, ir ši negalia būna iqveikiama N. Jonušaite „Sveikatos mokykla: ar tikrai čia susirenka tie, kurie nori sveikai numirti“ LR 1994-02-15. Kiti objektai skiriasi. Pirmojo laikotarpio tekstuose didžioji dalis minimų objektų nẻra labai pavojingi: tai drovumo barjerai, nuovargis, funkciniai miego sutrikimai, nepasitikèjimas, girtuokliavimas ir alkoholizmas. Pavojingesnès, bet apibūdinamos kaip ìveikiamos yra kraujo ligos ir mirtis: $\langle\ldots\rangle$ kokios buvo laimingos tos $d v i$ jaunos moterys, ịveikusios mirtị T. Tubinienè „Žmogus, kurio visi laukia“ KT 1984-11-27; Kraujo ligas bandoma ịveikti bendrom viso pasaulio mediku jegom R. Daškevičienè „Daktare, Jus kviečia“ KT 1986-02-19. Antrojo laikotarpio tekstuose minima daugiau sunkių ligų, kaip įveikiami priešai apibūdinami depresija, širdies ligos, aterosklerozè, gripas, psichinès ligos, vėžys: R. Oginskas „Depresiją ir blogą nuotaiką įveikti padeda vaistažolių arbata“ LR 1994-12-13; L. Lileikienè „Širdies ligas padeda įveikti ir psichologai“ LR 1995-11-28; Ji įsitikinusi, kad vežį įveikti gali tik chirurgo peilis L. Glodenienė „Dẻl ankstyvos panevéžietès mirties artimieji vis dar kaltina ekstrasensę“ LR 1996-10-06. Sutampa tie objektai, kurie abiejų laikotarpių tekstuose apibūdinami kaip nugalimi - nugalèti galima ligas ir baimę. Antrojo laikotarpio tekstuose kaip nugalimi dar minimi stresas ir nerimas, pirmojo laikotarpio tekstuose - alkoholizmas, plg.: Kai pamiršti ligq, ją daug lengviau nugaleti, priešingu atveju nugali liga Ž. Damauskas „Paauksuotas ir pasidabruotas adatas gali pakeisti tabletés“ LR 1994-0426; Jei gydytojui ar artimiesiems nepavyksta nugaleti ligonio nerimo, ligos prognoze gali pablogeti A. Laucevičius, K. Janulis „Streso kamuojami ligoniai jaučia net mirties baimę“ LR 1996-07-09; Vaistais nugalimos užkrečiamos 
ligos A. Vingras „Nematoma tabletės puse““ KT 1987-07-05; Alkoholizma tokiais atvejais galima nugaleti J. Pekarskis „Vaikščiojimas pakeltais tiltais“ KT 1987-06-26. Antrojo laikotarpio tekstuose minima daugiau dalyku ir reiškinių, nuo kurių iš(si)vaduojama. Tai skausmai, alkoholis, psichologinè priklausomybè, baimė, vėžys. Galima teigti, kad taip tekstuose užkoduota mintis, kad žmogus šiems priešams jau kartą yra pralaimẻjęs, patekęs ị jų nelaisvę ir buvęs priverstas atitinkamai elgtis. Aplinkybès susiklostè palankiai, todèl nuo to, kas nemalonu, pačiam pavyko išsivaduoti arba tai padejjo padaryti kiti žmonès: Išvaduoti iš skausmu moterị galettu tik sq̨nariu endoprotezavimo operacija I. Liutkevičienė „Ar tapsime invalidų tauta?“ LR 1992$12-18 ;<\ldots>$ pažistami ir pirmąkart čia išsivadavimo nuo bedugnès ieškantieji susikibę rankomis prašé $<\ldots>$ R. Lazauskaitè „Kauno anoniminių alkoholikų draugija: nutarę nebegerti žmonės už kiekvieną dieną dèkoja Dievui ir vienas kitam“ LR 1994-10-31; <...> ekstrasensas Jonas Kaminskas per kelis seansus jq išvaduos nuo ilgametès negalios R. Lazauskaitė „Ekstrasenso auką reikejjo reanimuoti“ LR 1995-05-02; Praëjusiq savaite iš gripo epidemijos išsivadavo ir vareniškiai „Gripas nesitraukia tik iš Šiaulių“ LR 2000-03-14.

Abiem lyginamiems laikotarpiams bendra yra pozityvi nuostata karo pabaigos atžvilgiu: daugiau linkstama aprašyti tuos atvejus, kurie pasibaigia ne ligos, o žmogaus pergale.

Apibendrinant tai, kas buvo pasakyta apie metaforinio KARO modelio temos Karo veiksmai ir ginklai turini 1980-1989 m. dienraščio „Komjaunimo tiesa“ ir 1990-2001 m. dienraščio „Lietuvos rytas“ tekstuose, galima teigti, kad lyginamų laikotarpių skirtumai atskleidžiami pateikiant su konkretesnėmis potemėmis siejamą informaciją. Tekstuose užuominos ị ginklus nėra gausios, minimi tie patys kariniai veiksmai, tačiau veiksmų objektai skiriasi, vadinasi, iš dalies skiriasi, yra pakitęs ir tekstuose užfiksuotas pasaulio suvokimas. Pokyčiai kalbos pasaulevvaizdyje nulemti aprašomojoje tikroveje įvykusių permainų: nepriklausomos valstybẻs atkūrimo išvakarėse imta drąsiau rašyti tokiomis temomis, kurios iki tol būdavo nutylimos: pradèti publikuoti straipsniai apie nepagydomas ligas, psichinę ir fizinę negalią turinčius žmones. Vis dèlto tai, kad iš esmès pasikeite valstybinè santvarka, teigiamų pavyzdžių šaltiniu imtas laikyti Vakarų pasaulis, iš viešojo diskurso nepašalino labiau su kairiosiomis ideologijomis siejamo metaforinio KARO modelio. Vadinasi, galima teigti, kad kalbamasis me- 
taforinis modelis labiausiai yra nulemtas ne tikrovès, apie kurią kalbama, aplinkybių, o apskritai žmonėms būdingos pasaulio suvokimo specifikos, t. y. buvusios TSRS erdvejje vyravusi visuotinès kovos atmosfera greičiau buvo palanki terpé metaforiniam KARO modeliui realizuoti, bet ne privaloma šio modelio taikymo sąlyga. Karo idejja ir toliau išlieka svarbi viešojo diskurso tekstuose. Visuomeninio ir politinio gyvenimo pokyčiai turi itakos tik konkretiems metaforinio modelio realizacijos atvejams. Metaforinis KARO modelis sveikatos diskurse paremtas jutimine ir kultūrine patirtimi, jis ir toliau lieka suprantamas karo neišgyvenusioms kartoms.

\section{Šaltiniai}

$\mathrm{KT}-$ „Komjaunimo tiesa“.

LR - „Lietuvos rytas“.

\section{Literatūra}

Arcimavičienė 2010a - Liudmila Arcimavičienè. Morality models through metaphors in public discourse: a cross-linguistic analysis. Daktaro disertacija. Vilnius: Vilniaus universitetas.

Arcimavičienè 2010b - Liudmila Arcimavičienè. Terrorism in media political discourse: from metaphorical expressions to cognitive models. Verbum, t. 1, 7-16.

Arcimavičienè 2011 - Liudmila Arcimavičienè. The complex metaphor of political animals in media political discourse: a cross-linguistic perspective. Kalbu studijos, nr. 19, 95-100.

Baronas 2000 - Darius Baronas. Lietuvių karyba XIII a. Karo archyvas XVI. Atsakingasis redaktorius ir sudarytojas dr. Gintautas Surgailis. Vilnius: LR krašto apsaugos ministerija, 4-48.

Girčienė 2011 - Jurgita Girčienè. Viešasis diskursas kreipimosi į adresatą požiūriu: neformalumo link. Gimtasis žodis, nr. 5, 2-39.

Juzelènienė, Baranauskienė 2011 - Saulè Juzelėnienė, Rita Baranauskienė. Solidarumo komunikacinės taktikos raiška politiniame diskurse. Kalbu studijos, nr. 19, 101-105.

Lakoff, Johnson 1998 - George Lakoff, Mark Johnson. Leben in Metaphern: Konstruktion und Gebrauch von Sprachbildern. Heidelberg: Carl-Auer-Systeme, Verl. und Verl.-Buchh.

Linkevičiūtè 2011 - Vilma Linkevičiūtè. Conflict communication discourse of political leaders of Lithuania and Great Britain (1998-2008): rhetorical-cognitive peculiarities. Daktaro disertacija. Vilnius: Vilniaus universitetas.

Marcinkevičienė 1995 - Rūta Marcinkevičienė. Karo metafora. Darbai ir dienos, 1(10), 121-124.

Rudaitienè 2011 - Vida Rudaitienè. Globalizacija ir leksikos pokyčiai politiniame diskurse. Res humanitariae X, 256-283.

Šeškauskienė, Urbonaitė 2007 - Inesa Šeškauskienė, Justina Urbonaitė. HEALTH metaphor ir political and economic discourse: a cross-linguistic analysis. Kalbų studijos, nr. 11, $68-73$.

Šukys 1978 - Jonas Šukys. Prielinksnių vartojimas. Kaunas: Šviesa. 
Vaskelienė 2007 - Jolanta Vaskelienè. Trumpas teksto lingvistikos žinynas. Šiauliai: Šiaulių universiteto leidykla.

Баранов, Михайлова, Шипова 2006 - Анатолий Баранов, Ольга Михайлова, Евгения Шипова. Некоторые константы русского политического дискурса сквозь призму политической метафорики ('взаимоотношения бизнеса и власти', 'коррупция'). Москва: Фонд ИНДЕМ.

Голев, Шпильная 2012 - Николай Голев, Надежда Шпильная. Обыденная медицинская коммуникация (виды дискурсивных практик). Вестник КемГУ, 1(49), 128-138.

Зубкова 2005 - Ольга Зубкова. Феномен медицинской метафоры. Теория языка и межкультурная коммуникация: Межвузовский сборник научньхх трудов / Под ред. Т. Ю. Сазоновой. Курск, Изд-во Курск, гос. ун-та, 38-47.

Зубкова 2007 - Ольга Зубкова. Функционирование медицинской метафоры. Теория языка и межкультурная коммуникация: Межвузовский сборник научных трудов. / Под ред. Т. Ю. Сазоновой. Курск, Изд-во Курск, гос. ун-та, 26-29.

Жура 2008 - Виктория Жура. Дискурсивные эмоции в устной медицинской коммуникации. Мир лингвистики и коммуникации: электронный научный журнал, 1(10). Тверь: Тверская государственная сельскохозяйственная академия, 13-23.

Коницкая, Запольский 2011 - Елена Коницкая, Артур Запольский. Метафорика литовского и словенского политического дискурса. Respectus philologicus, nr. 20 (25), 243-253.

Корнилов 1999 - Олег Корнилов. Языковые картины мира как производные национальных менталитетов. Москва: Издательство МГУ.

КСКТ 1996 - Елена Кубрякова, Владимир Демьянков, Юрий Панкрац, Людмила Лузина. Краткий словарь когнитивных терминов. Москва: Изд-во Филологического факультета МГУ.

Мишланова 2002 - Светлана Мишланова. Метафора в медицинском дискурсе. Пермь.

Мишланова 2009 - Светлана Мишланова. Метафорическое моделирование в научнопопулярном медицинском дискурсе. Актуальныле проблемы коммуникации и культурьг: междунар. сб. науч. тр. М.; Пятигорск: Пятигор. гос. ун-т, вып. 9, 469-474.

Рудова 2008 - Юлия Рудова. Буклет как жанр письменного медицинского дискурса. Вестник Волгоградского государственного университета. Серия 2. Волгоград: Волгоградский государственный университет, 1 (7), 110-115.

Соломенникова 2012 - Татьяна Соломенникова. Типы вербализации концептов в медицинском дискурсе. Глобальный научный потенциал, 6(15), 27-32.

Стернин 1998 - Иосиф Стернин. Национальная специфика мышления и проблема лакунарности. Связи языковых единиц в системе и реализации: Межвузовский сборник научных трудов. Тамбов: Изд-во Тамбовского ун-та, 22-31.

Таценко, Москаленко, Переломова, Кондратюк, Безуглый 2012 - Наталия Таценко, Роман Москаленко, Елена Переломова, Александр Кондратюк, Михаил Безуглый. Особенности медицинского дискурса в практике врача-патологоанатома. Морфологія, т. VI, 2, 5-8.

Чудинов 2001 - Анатолий Чудинов. Россия в метафорическом зеркале: когнитивное исследование политической метафоры. Екатеринбург.

Чудинов 2003 - Анатолий Чудинов. Метафорическая мозаика в современной политической коммуникации. Екатеринбург: [prieiga internetu: http://www.philology.ru/ linguistics2/chudinov-03a.htm Екатеринбург, žiūrèta 2013-02-14]. 


\section{Silvija Papaurèlytè}

\section{METAPHORICAL MODEL OF WAR IN HEALTH DISCOURSE OF LITHUANIA (1980-2001)6}

Summary

The aim of the research described in the present article is to compare how in Lithuanian public discourse of 1980-1989 and 1990-2001 years, metaphorical WAR model was realized. The material has been drawn from the issues of daily newspaper Komjaunimo tiesa of 1980-1989 years and daily newspaper Lietuvos rytas of 1990-2001 years ${ }^{7}$. The conclusions of the research are substantiated with the analysis of 217 examples. The attention is paid to the articles about diseases, causes of diseases, histories of treatment and health, doctors' job, the specificity of the system of healthcare, i.e. the discourse of health, that in Lithuanian linguistics has not been described yet.

The article is based on cognitive approach to language. It is strived to describe the specificity of health discourse through the analysis of metaphorical WAR model. Metaphorical model - the scheme existing in language users' consciousness and/or resulting in the relation between concrete and abstract spheres of concepts, that is reflected by the formula $\mathrm{X}$ is Y, for example: PROCESS OF TREATMENT is WAR. The relation between the components of formula is understood not as identification but as similarity. The typical scenarios, which are related to metaphorical model, involve the situations that are relevant to the sphere of sources. The content of one situation is revealed by several themes. The description of subthemes that are related to the themes may provide more information. The subordinate relations in typical scenario, themes and subthemes may be considered as tertium comparationis in striving to evaluate the similarities and differences of world perception that is inherent to different languages or different periods. If an abstract phenomenon is perceived in applying metaphorical WAR model, the essence of this abstract phenomenon is

6 The presentation is prepared while implementing scientific project "Conceptual Metaphors in Public Discourse" financed by Research Council of Lithuania, No. VAT-12022.

7 The period till 1990 is called the first and since March, 1990 till 2001 - the second. 
composed of the collision of two or more subjects, after which one winner usually remains. Other party of the conflict either dies or severely suffers.

While collecting the examples of health discourse from the issues of daily newspaper Komjaunimo tiesa of 1980-1989 years and daily newspaper Lietuvos rytas of 1990-2001 years it was observed that there is a tendency of frequent usage of metaphorical WAR model while talking about a person's health state. In 1980-1989, the texts of public discourse had to obey to the totalitarian ideas and to reveal the general atmosphere of fight. The second period, i.e. the last decade of XX c., stands out as a time of major changes: in 1990-2001 years, Lithuania proclaimed that it would reestablish the independent state, the political parties started to appear, thus the idea of fight remains important further. The equal durations, i.e. the periods of 10 years are chosen for the analysis. Not always the same attention was paid to the health themes in the public discourse. In the beginning of the ninth decade, only few articles were published, that may be considered as a part of health discourse.

In the texts that belong to the periods of 1980-1990 and 1990-2001 years, the themes of War Activities and Arms and War Beginning and its Results are revealed in detail.

The fight objects in the texts of 1980-1989 and 1990-2001 years coincide only partially - the exact diseases that are mentioned in the texts differ. Among these diseases, fight with which it was not important to describe in the texts of the first period, there are only few, which people began to suffer with namely in the end of XX c. Part of the themes in the texts of 1980-1989 years were, apparently, simply ignored. It should be mentioned that the authors of the texts of that period wrote that it ought to be fought not only with the diseases but also with peoples' bad behavior that could lead to the diseases. In the texts of the first period, the possibility was foreseen to fight for the healthy environment, healthy way of living, healthy person, healthy Lithuanian citizen, healthy and honest youth. The analysis of the examples of the second period revealed that the attention is paid to describe the number of war participants. The theme of arms was revealed in more detail in the texts of the second period. The theme War Beginning and its Results in the texts of the analyzed periods is revealed differently. For the second period it is appropriate that more serious diseases that may be overcome are described. The positive 
provision is common for both periods under comparison from the point of view of war end: there was a tendency to describe the cases that end not in disease but in person's victory.

The conclusion could be drawn that the differences of the periods under comparison are revealed while realizing the information which is related to more exact subthemes. The allusions to arms in the texts are not prolific, the same war activities are mentioned, however, the objects of activities are different, thus, the world perception is changed and recorded in the texts. The changes in language world view are determined by the occurred changes in the reality under description. On the other hand, this that the system of government has changed substantially, the Western world was started to be considered as the source of positive examples, that did not eliminate metaphorical WAR model from public discourse. Thus, this metaphorical model is mostly determined not by the circumstances of reality, which is talked about, but by the specificity of the world perception which is relevant for people. 